\title{
Profil Kondisi Psikis Atlet Putra Sepak Takraw Sumut Pelatda PON XX
}

\author{
Ibrahim Wiyaka, Adikahriani, Soewandi \\ Fakultas Ilmu Keolahragaan, Universitas Negeri Medan, \\ ibrahimwiyaka10@gmail.com
}

\begin{abstract}
Abstrak: Penelitian ini bertujuan mengidentifikasi profil kondisi psikis atlet atlet putra sepak takraw Sumut Pelatda PON tahun 2020. Metode yang digunakan dalam penelitian ini adalah metode survei dengan desain penelitian expost facto. Populasi dalam penelitian ini adalah atlet putera sepak takraw Sumut yang akan dipersiapkan menuju PON XX. Teknik pengambilan sampel dalam penelitian ini menggunakan purposive sampling dengan kriteria Atlet sepak takraw Sumut yang telah melaksanakan pemusatan latihan. Berdasarkan itu, maka didapat sampel penelitian atlet cabang olahraga sepak takraw yang berjumlah 4 atlet. Pengumpulan data menggunakan kuesioner. Hasil penelitian menunjukan profil kondisi psikis atlet sepak takraw Sumut Pelatda PON dalam hal komitmen diperoleh skor 84 - 87 dengan kategori tinggi, Adapun percaya diri diperoleh skor 76 - 90 dengan kategori tinggi.
\end{abstract}

Kata Kunci: Sepak Takraw, Komitmen, Percaya Diri

\section{Profile of The Psychological Condition of The Male Athletes of Sepak Takraw North Sumatera Pelatda PON XX}

\begin{abstract}
This study aims to identify the profile of the psychological condition of the male athletes of male sepak takraw athletes from North Sumatra Pelatda PON in 2020. The method used in this study is a survey method with an ex post facto research design. The population in this study were male athletes of sepak takraw of North Sumatra who will be prepared for PON XX. The sampling technique in this study used purposive sampling with the criteria of North Sumatran sepak takraw athletes who had carried out training camps. Based on that, the research sample of sepak takraw athletes, totaling 4 athletes, was obtained. Collecting data using a questionnaire. The results showed the profile of the psychological condition of the athletes of sepak takraw in North Sumatra Pelatda PON in terms of commitment, a score of 84 - 87 was obtained in the high category, while for self-confidence, a score of 76 - 90 was obtained in the high category.
\end{abstract}

Keywords: Sepak Takraw, commitment, self-confidence

\section{PENDAHULUAN}

Meraih prestasi yang maksimal membutuhkan usaha dan kerja keras, berupa latihan yang terencana, terukur dan berkesinambungan. Latihan yang dilakukan harus sesuai dengan kebutuhan cabang olahraga yang dilakukan dan unsur fisik, teknik, dan psikis yang dominan, sehingga unsurunsur fisik itulah yang dibangun dan ditingkatkan melalui proses latihan. Selain itu, apabila kondisi fisik atlet dalam keadaan baik, maka atlet akan lebih cepat menguasai teknik-teknik gerakan yang akan ditampilkan pada saat bemain.

Pada pencapaian prestasi yang tinggi didalam olahraga dibutuhkan persiapan terpadu dan berkesinambungan antara unsur-unsur fisik, teknik, dan psikis. Di sisi lain untuk mencapai prestasi dalam cabang olahraga sepak taktaw, latihan untuk peningkatan kemanpuan kondisi fisik, teknik, dan 
psikis merupakan hal yang sangat penting, karena kondisi fisik, teknik, dan psikis yang baik akan membantu atlet untuk mempermudah melakukan dan menguasai teknik-teknik dasar. Begitu pula halnya dalam sepak takraw, komponen-komponen fisik, teknik, dan psikis berperan penting karena ketiga hal tersebut merupakan satu kesatuan yang utuh tak terpisahkan. Kurangnya dari salah satu hal tersebut akan berdampak dan mempengaruhi penampilan seorang atlet baik saat latihan maupun pada saat bertanding/berlomba.

Karageorghis dan Terry (2011) menyatakan untuk mendapatkan prestasi yang baik dalam olahraga perlu menggabungkan tiga komponen penting yang menunjang prestasi atlet yaitu kondisi fisik untuk kompetisi, tingkat keterampilan, dan persiapan psikologis untuk bersaing. Kunci perbedaan antara penampilan yang baik dan penampilan yang buruk adalah terletak pada tingkatan keterampilan psikologis pemain yang lebih baik dibandingkan dengan keterampilan fisik. Aspek mental atau psikologis harus mendapatkan porsi latihan yang sama dengan keterampilan fisik, teknik, dan taktik untuk mendapatkan penampilan terbaik atlet.

Menyadari akan pentingnya pembentukan fisik, teknik, dan psikis adalah suatu persyaratan yang sangat diperlukan dalam usaha peningkatan prestasi seorang atlet, bahkan dapat dikatakan sebagai keperluan dasar yang tidak dapat dipisahkan dan ditunda atau ditawar-tawar lagi. Weinberg dan Gould (2011) dalam penelitiannya mengungkapkan keberhasilan dan kegagalan pemain dalam olahraga prestasi sangat ditentukan oleh perpaduan dari kemampuan faktor fisik dan psikologis bahkan untuk cabang olahraga tertentu faktor psikologis tersebut mencapai $80 \%$ sampai $90 \%$. Begitu juga menurut Lutan (2010) bahwa atlet harus memiliki keterampilan psikologis dan moral yang diperlukan oleh cabang olahraga yang ditekuninya untuk berprestasi.

Atlet putera sepaktakraw PON Sumut, yang sekarang mempersiapkan diri dengan pembenahan segala kekurangan yang terdapat pada atlet khususnya pada aspek kondisi psikis dalam hal komitmen dan keperyaan diri perlu menjadi perhatian, Karena aspek ini terkadang terabaikan, padahal sangat menentukan dalam menyusun dan menjalankan program yang telah disusun oleh pelatih. Terkadang kondisi fisik dan teknik yang dimiliki oleh atlet sudah cukup tinggi dan akan buyar dan hilang disebabkan oleh unsur kondisi psikis/mental atlet yang tidak siap menghadapi kenyataan yang dialamami baik saat latihan maupun bertanding.

Komitmen dan kepercayaan diri yang dimiliki oleh seorang atlet perlu mendapat perhatian dari Pembina/pelatih untuk mengukur sampai dimana kesiapan atlet dalam mengahadapi kejuaran yang akan diikuti, apa mereka hanya sekedar ingin ikut kejuaraan atau memang ingin berprestasi.

Istilah komitmen terdiri dari dari yaitu "Commitment" berarti tujuan. Dengan demikian, komitmen merupakan suatu kemampuan merancang atau komitmen diajukan yang hendak dicapai. Komitmen memiliki peranan penting terutama pada kinerja seseorang ketika beraktivitas sepak takwa dalam latihan, hal ini disebabkan oleh adanya komitmen yang menjadi acuan serta dorongan yang membuat mereka lebih bertanggung jawab terhadap kewajibannya.

Panggabean (2010: 01) menjelaskan bahwa eksistensi komitmen pada diri atlet dapat dilihat dari beberapa indikator: (1) kecintaan pada perannya;(2) kepercayaan pada misi dan tujuan yang sedang dibebankan kepadanya; (3) keter-ikatan untuk menjaga nama baik perannya; (4) tanggapan terhadap tantangan yang ada; (5) dan keikhlasan dalam menjalankan tugasnya. Untuk mengevaluasi penampilan atlet sepak takraw baik dalam aspek kematangan personal dan penampilan puncaknya prestasi, ada beberapa fisik, teknik, dan psikis atau metode latihan psikologi yang perlu diretapkan, salah satunya adalah komitmen.

Komitmen merupakan salah satu teknik yang sangat efektif untuk memotivasi atlet untuk mencapai suatu tujuan. Pencapain tujuan harus didasarkan pada persiapan dan proses yang dilakukan secara matang sehingga komitmen menjadi efektif tidak hanya memfasilitasi atlet sepak takraw dalam mencapai performa maksimalnya, tetapi juga penting untuk mengatasi masalah psikologi lainnya, seperti kecemasan, kepercayaan diri, dan komitmen. Kemampuan untuk komitmen perlu dimiliki oleh pelatih dan atlet. Komitmen merupakan salah satu pondasi yang baik untuk mencapai sukses dalam program latihan kerampilan mental. Hal ini dikarenakan bahwa pelatih dan atlet dapat mencapai keberhasilan baik fisik, teknik dan psikis, melalui penerapan prinsip komitmen.

Selain Aspek komitmen yang perlu diperhatikan pada diri atlet, aspek percaya diri juga tak kalah pentingnya. Hal ini dapat dilihat dari berbagai definisi yng dikemukakan oleh para ahli 
diantaranya adalah: Gunarsa (2008: 10) Percaya diri merupakan aspek kepribadian yang mutlak yang harus dimiliki oleh sesorang olahragwan bidang olahrga apapun karena berkaitan dengan keyakinan "aku bisa". Selanjtnya menurut Fodor (2009: 67), Self confidence is a key concept in today's successdriven society, which,for many people. (Percaya diri adalah kunci dalam masyarakat yang berorientasi pada kesuksesan saat ini bagi banyak orang). Tucker (2015: 18), Self confidance is how you view your abilities and will vary from situation to situation (keyakinan diri adalah bagaimanan anda melihat kemampuan anda bervariasi dari situasi ke siatuasi yang lain). Berikutnya menurut Horn (2008: 66) mendefiniskan Self-confidence sebagai keyakinan bahwa seseorang memiliki sumber daya interna, terutama kemampuan, untuk mencapai keberhasilan, maksudnya Self-confidence berakar pada keyakinan dan harapan. Self-confidence merupakan modal utama seorang atlet untuk maju karena pencapaian prestasi yang tinggi harus dimulai dengan percaya bahwa mampu dan sanggup melampuai prestasi yang pernah diraih (Setyobroto, 2002: 43).

Self-confidence adalah aspek rasa percaya pada kemampuan sendiri bahwa mampu mencapai prestasi pelatda PON tertentu dan apabila prestasinya sudah tinggi makan individu tersebut akan lebih self-confidence. Self-confidence akan menimbulkan rasa aman yang dapat dilihat dari sikap dan tingkah laku pada saat latihan yang tampak tenang, tidak mudah ragu-ragu tidak mudah gugup, dan tegas. Atlet sepakt akraw yang penuh percaya diri (full-confidence) biasanya menetapakan target sesuai dengan kemampuan sehingga berusaha untuk mencapai target tersebut. Apabila mengalami kegagalan, akan di hadapi dan diterima dengan lapang dada tanpa harus frustasi.

Ciri atau karakteristik individu yang memiliki rasa percaya diri yang proporsional (optimal) yaitu: a) Percaya kan kompetensi/kemampuan diri, hingga tidak membutukan pujian, pengakuan, penerimaan, ataupun hormat orang lain. b), Tidak terdorong untuk menunjukkan sikap komformis demi diterima oleh orang lain atau kelompok. c), Berani menerima dan menghadapi penolakan orang lain, berani menjadi diri sendiri, d), Punya pengendalian diri yang baik (tidak moody dan emosi stabil). e), Memiliki internal focus of control (memandang keberhasilan atau kegagalan, bergantung pada usaha deiri sendiri dan tidak mudah menyerah pada nasib atau keadaan serta tidak tergantung/mengharapkan bantuan orang lain). f), Mempunyai cara pandang yang positif terhadap diri sendiri, orang lain, dan situasi diluar dirinya, g), Memiliki harapan yang realistis terhadap diri sendiri, sehingga harapan itu tidak terwujud, ia tetap mampu melihat sisi positif dirinya dan situasi yang terjadi. Enung Fatimah $(2010: 149)$

\section{METODE}

Metode penelitian mengunakan survei dengan desain penelitian expost facto. Penelitian dilaksanakan pada bulan Oktober 2019 di Kota Medan. Pengumpulan data dilakukan di Unversitas Negeri Medan. Populasi yang digunakan dalam penelitian ini adalah atlet putera Pelatda PON Sumut yang akan dipersiapkan pada PON Papua XX tahun 2021. Teknik pengambilan sampel menggunakan purposive sampling dengan syarat atlet sepak takraw PON. Jumlah sampel yang diperoleh yaitu 4 atlet sepak takraw. Dimensi yang diukur. Dimensi yang diukur adalah: 1) membulatkan hati atau niat terhadap berbagai gangguan baik dari emosi maupun kehidupannya, 2) bertekad, sikap percaya kepada kemampuan diri sendiri untuk mengatasi persoalan. 3) berkorban, sikap memberikan segalanya demi tujuan yang ingin dicapai dan 4) motivasi 5) bertangggung jawab, sikap yang siap dengan berbagai risiko dalam memandang suatu tantangan.

Self confidence dapat ditingkatkan/dibangun dalam berbagai cara antara lain seperti acompplising melalui kinerja, bertindak percaya diri, berpikir percaya diri, menggunakan citra, menggunakan tujuan maping, optimis pada kondisi fisik, dan mempersiapkan semuanya sebelum bertanding. 
Tabel 1. Norma Tes Komitmen dan Percaya Diri

\begin{tabular}{ccl}
\hline NO & Norma & Psertasi Komitmen \\
\hline $\mathbf{1}$ & SS & Sangat setuju \\
\hline $\mathbf{2}$ & ST & Setuju \\
\hline $\mathbf{3}$ & RR & Ragu-ragu \\
\hline $\mathbf{4}$ & TS & Tidak Setuju \\
\hline $\mathbf{5}$ & STS & Sangat Tidak Setuju \\
(Sumber: (2018) Sport Psychometrics Dasar-dasar dan Instrumen Psikometri)
\end{tabular}

\section{HASIL DAN PEMBAHASAN}

Profil Kondisi Psikis (Komitmen) Atlet Putera Sepak Takraw Sumut.

Berdasarkan hasil penelitian menunjukkan bahwa komitmen atlet putera sepak takraw Sumut berada pada skor 84 - 87 kategori tinggi, namun bila dibanding dengan skor tertinggi yaitu 125, maka kondisi komitmen atlet masih perlu ditingkatkan dengan berbagai cara dari pelatih, pembina. Hal ini dapat dilihat pada tabel berikut:

Tabel 2. Kriteria Hasil Jawaban Kuesioner

\begin{tabular}{ccc}
\hline No & Skor & Keterangan Tingkat \\
\hline 1 & $91-125$ & Penuh \\
\hline 2 & $76-90$ & Tinggi \\
\hline 3 & $51-75$ & Sedang \\
\hline 4 & $26-50$ & Rendah \\
\hline 5 & $0-25$ & Tidak Memiliki \\
\hline \multicolumn{2}{r}{}
\end{tabular}

Berdasarkan kedua hasil kuesioner di atas dan berdasarkan hasil scoring maka dapat digolongkan sebagai berikut:

Tabel 3. Hasil Kuesioner Komitmen

\begin{tabular}{cccc}
\hline No & $\begin{array}{c}\text { Butir } \\
\text { Item }\end{array}$ & $\begin{array}{c}\text { Skor } \\
\text { Komitmen }\end{array}$ & $\begin{array}{c}\text { Keterangan } \\
\text { Komitmen }\end{array}$ \\
\hline 1 & 25 & 87 & Tinggi \\
\hline 2 & 25 & 85 & Tinggi \\
\hline 3 & 25 & 84 & Tinggi \\
\hline 4 & 25 & 85 & Tinggi \\
\hline \multicolumn{4}{c}{ Sumber Hasil Penelitian 2020 } \\
\end{tabular}

Komitmen merupakan salah satu pondasi yang baik untuk mencapai sukses dalam program latihan kerampilan mental. Hal ini dikarenakan bahwa pelatih dan atlet dapat mencapai keberhasilan baik fisik, teknik dan psikis, melalui penerapan prinsip komitmen. Komitmen memiliki peranan penting terutama pada kinerja seseorang ketika beraktivitas sepak takraw dalam latihan, hal ini disebabkan oleh adanya komitmen yang menjadi acuan serta dorongan yang membuat mereka lebih bertanggung jawab terhadap kewajibannya.

Panggabean (2010: 01) menjelaskan bahwa eksistensi komitmen pada diri atlet dapat dilihat dari beberapa indikator: (1) kecintaan pada perannya; (2) kepercayaan pada misi dan tujuan yang sedang dibebankan kepadanya; (3) keter-ikatan untuk menjaga nama baik perannya; (4) tanggapan terhadap tantangan yang ada; (5) dan keikhlasan dalam menjalankan tugasnya. Komitmen merupakan salah satu teknik yang sangat efektif untuk memotivasi atlet untuk mencapai 
suatu tujuan. Pencapain tujuan harus didasarkan pada persiapan dan proses yang dilakukan secara matang sehingga komitmen menjadi efektif tidak hanya memfasilitasi atlet sepak takraw dalam mencapai performa maksimalnya, tetapi juga penting untuk mengatasi masalah psikologi lainnya, seperti kecemasan, kepercayaan diri.

\section{Profil Kondisi Psikis (Percaya Diri) Atlet Putera Sepak Takraw Sumut}

Berdasarkan hasil peneltian menunjukkan bahwa rasa percaya diri atlet putera sepak takraw Sumut berada pada skor 76 - 90 kategori tinggi, namun bila dibanding dengan skor tertinggi yaitu 125, maka kondisi komitmen atlet masih perlu ditingkatkan dengan berbagai cara dari pelatih, pembina. Hasil ini juga menunjukkan bahwa dari 4 atlet yang diteliti, terdapat 1 atlet yang percaya dirinya masih pada tahap minimal walaupun masih dalam kategori tinggi. Ini suatu gambaran bahwa percaya diri dari atlet masih perlu ditingkatkan. Hal ini dapat dilihat pada tabel berikut:

Tabel 4. Kriteria Hasil Jawaban Kuesioner

\begin{tabular}{ccc}
\hline No & Skor & Keterangan Tingkat \\
\hline 1 & $91-125$ & Penuh \\
\hline 2 & $76-90$ & Tinggi \\
\hline 3 & $51-75$ & Sedang \\
\hline 4 & $26-50$ & Rendah \\
\hline 5 & $0-25$ & Tidak Memiliki \\
\hline \multicolumn{3}{c}{ Sumber Hasil Penelitian 2020 }
\end{tabular}

Berdasarkan kedua hasil kuesioner di atas dan berdasarkan hasil scoring maka dapat digolongkan sebagai berikut :

Tabel 5 : Hasil Kuesioner Percaya Diri

\begin{tabular}{cccc}
\hline No & Butir & Skor & Keterangan \\
\cline { 3 - 4 } & Item & Percaya Diri & Percaya Diri \\
\hline 1 & 25 & 90 & Tinggi \\
\hline 2 & 25 & 76 & Tinggi \\
\hline 3 & 25 & 88 & Tinggi \\
\hline 4 & 25 & 88 & Tinggi \\
\hline & & Sumber Hasil Penelitian 2020
\end{tabular}

Self-confidence (percaya diri) merupakan aspek percaya diri yang mutlak yang harus dimiliki oleh seorang atlet sepak takraw apa pun karena berkaitan dengan keyakinan "saya bisa". Didalam upaya mengikatkan percayaan diri pada atlet sepakt akraw akan lebih baik apabila dilakukan oleh psikis yang menerapkan berbagai pendekatan disesuaikan dengan kepribadian atlet dan dilakukan secara terjadwal. Sebagaian besar pelatih atau atlet berpikir bahwa percaya arti percaya timnya akan menang atau mengungguli lawannya. Dalam pertandingan olahraga pun, sering terdegar kalimat, "jika saya bisa memenangi beberapa pertandingan, rasa percaya diri saya mungkin akan kembali lagi". Bersadarkan kalimat tersebut, dapat dilihat bahwa percaya diri hampir selalu dianggap sebagai sesuatua yang terjadi di dalam diri si pemain, buka suatu yang dapat dikendalikan. Kemenangan atau sukses dalam beberapa pertandingan dianggap sebagai satu-satunya cara nyata untuk meraih kepercayaan diri.

Kepercayaan diri akan sangat membantu aspek seseorang atlet sepak takraw dalam melakukan berbagai aktivitas. Sebagian besar pelatih dan atlet sepak takraw berpikir bahwa percaya diri berarti percaya timnya akan menang atau mengungguli lawannya. Kemenangan atau sukses dalam beberapa pertandingan dianggap sebagai satu-satunya cara nyata untuk meraih kepercayaan diri (Apta Mylsidayu, 2014: 103). 
Tabel 6. Gambaran Hasil Kuesioner Atlet Sepak Takraw

\begin{tabular}{cccccc}
\hline \multirow{2}{*}{ No } & Butir & \multicolumn{2}{c}{ Skor } & \multicolumn{2}{c}{ Keterangan } \\
\cline { 3 - 6 } & Item & Komitmen & Percaya Diri & Komit & P.Diri \\
\hline 1 & 25 & 87 & 90 & Tinggi & Tinggi \\
\hline 2 & 25 & 85 & 76 & Tinggi & Tinggi \\
\hline 3 & 25 & 84 & 88 & Tinggi & Tinggi \\
\hline 4 & 25 & 85 & 88 & Tinggi & Tinggi \\
\hline
\end{tabular}

\section{SIMPULAN}

Dari hasil penelitian yang dipaparkan dapat disimpulkan bahwa profil kondisi psikis atlet sepak takraw Sumut Pelatda PON dalam hal komitmen dan percaya diri pada kategori tinggi meskipun jika dibandingkan dengan tabel kriteria skor hasil jawaban yaitu 125, maka kondisi komitmen atlet masih perlu ditingkatkan lagi melalui berbagai cara dari pelatih maupun pembina cabang olahraga. Kondisi psikis adalah hal yang penting untuk diperhatikan dalam pencapaian prestasi dimana perlu kiranya dibina dan dikembangkan oleh pelatih maupun ahli psikologi yang bertugas disana sehingga tujuan prestasi yang ditetapkan dapat tercapai. Sering kali terjadi atlet pada saat bertanding tidak dapat menguasai kondisi psikisnya sehingga mempengaruhi pertandingan yang diikuti padahal sudah berlatih cukup lama. Oleh karena itu kondisi psikis atlet menjadi salah satu hal yang penting untuk diperhatikan dalam pembinaan prestasi atlet untuk mencapai prestasi terbaik.

\section{DAFTAR PUSTAKA}

Fatimah, E. (2010). Psikologi Perkembangan (Perkembangan Peserta Didik). Bandung: Pustaka Setia

Fodor, Miklos, (2009). Self-expansion; Redifining Key Psychology Terms With System Theory, USA: Academic Edition.

Horn, T. S. (2008). Advances in sport psychology. 3rd edition. Ohio: Human Kinetics.Inc.

Karageorghis, C. I., \& Terry, P. C. (2011). Inside Sport Psychology. Champaign: Human Kinetics.

Lutan, R. (2010). Modul Mata Kuliah Sejarah dan Filsafat Olahraga. Bandung: FPOK UPI.

Panggabean, Rizal. (2010). Komitmen dan De-komitmen. http://diahkei.staff.ugm.ac.id

Singgih D. Gunarsa (2008). Psikologi Olahraga Presatasi. Jakarta: Gunung Mulia.

Setyobroto, Sudibyo. (2002). Psikologi Olahraga. Jakarta: Unit Percetakan UNJ.

Tucker, Elizabeth J. (2015). A Matter Of Self-confidace; Part 1 Introduction To SelfConfidence Coaching In A Book. UK: Shepherd Creative Learning.

Weinberg, R. S., \& Gould, D. (2011). Foundations of Sport and Exercise Psychology: Welcome to Sport and Exercise Psychology. Human Kinetics. 